\title{
Isolation of a candidate gene \\ for Menkes disease and \\ evidence that it encodes a copper-transporting ATPase
}

C. Vulpe, B. Levinson, S. Whitney, S. Packman \& J.

Gitschier

Nature Genetics 3, 7-13 (1993)

Further analysis of the predicted protein indicates at least one, and possibly two, additional transmembrane domains. The first of these lies between amino acids 653 and 675 and would constitute the initial transmembrane domain. Amino acids residues 780 to 798 could comprise an additional transmembrane domain, resulting in four hairpins, rather than three.

\section{Human genes containing polymorphic trinucleotide repeats}

G. J. Riggins, L. K. Lokey, J. L. Chastin, H. A. Leiner, S. L. Sherman, K. D. Wilkinson \& S. T. Warren Nature Genetics 2, 186-191 (1992)

In this article the authors inadvertently referred to the gene GST1 (accession no. X17644) as glutathione-Stransferase when, in fact, the sequence identified was that of $\mathrm{G}_{1}$ to $\mathrm{S}$ transition locus (Hoshino, et al., EMBO J. 8, $3807 ; 1989$ ).

\section{Aberrant splicing of neural cell adhesion molecule L1 mRNA in a family with $X$-linked hydrocephalus}

A Rosenthal, M Jouet \& S Kenwrick

Nature Genetics 2, 107-112 (1992)

A sentence in the fourth paragraph of the discussion of this paper should have read: The $69 \mathrm{bp}$ insertion could yield a protein with 23 amino acids inserted between type III domains 2 and 3 but with all domains still intact. 